\title{
Osobne značajke i životni ciljevi grupe obožavatelja Cellogirls
}

\author{
Tea Gutović
}

Sveučilište u Zagrebu, Filozofski fakultet, Hrvatska

e-mail: tgutovic@gmail.com

\section{In a Reić Ercegovac}

Sveučilište u Splitu, Filozofski fakultet, Katedra za psihologiju, Hrvatska e-mail: inareic@ffst.hr

\begin{abstract}
SAŽETAK Pojam obožavatelja i njihovih grupa nije jednostavan predmet analize i istraživanja. Nužno ga je smjestiti u društveni i kulturni kontekst kako bi se adekvatno shvatile i proučile njegove karakteristike, kako pojedinaca tako i grupa obožavatelja sa svim njihovim načelima, aktivnostima i uobičajenim ponašanjima. U ovom je radu predstavljeno istraživanje nekih značajki obožavatelja instrumentalnog dua 2CELLOS, provedeno na uzorku od 188 sudionika iz cijeloga svijeta. Primijenjena je online inačica anketnog upitnika, koji se sastojao od pitanja zatvorenog tipa kojima su se prikupili podaci o relevantnim sociodemografskim obilježjima sudionika, te skraćene verzije skale za ispitivanje važnosti životnih ciljeva. Rezultati su pokazali kako skupina obožavatelja nije homogena prema svojim sociodemografskim obilježjima, iako većinu čine žene mlađe životne dobi, višeg stupnja obrazovanja, heteroseksualne orijentacije, bez jasnih političkih afiniteta, s nekim oblikom glazbenog obrazovanja i iskustva. Što se tiče važnosti životnih ciljeva, sudionici su najvažnijima procijenili ciljeve intimnosti i postignuća.
\end{abstract}

Ključne riječi: obožavatelji, 2CELLOS, Cellogirls, sociodemografske značajke, glazba, životni ciljevi. 


\section{Uvod}

Termin „obožavatelj“ pojavljuje se u sportskom kontekstu krajem 19. stoljeća u SADu, a danas većina može predočiti što on podrazumijeva, kao i koja su obilježja pojedinaca koji pripadaju određenoj grupi obožavatelja (engl. fandom ${ }^{1}$ ) (Cavicchi, 1998.; Hills, 2002.). Sukladno jednom od shvaćanja etimologije termina, koje riječ fan povezuje s riječju fanatic pridajući joj tako povijesno utemeljenu konotaciju i povezujući je s pridjevima kao što su „pomahnitali“ ili „opsjednuti“, suvremenog se obožavatelja opisuje pojmom opsesije usmjerene prema nekoj zvijezdi, filmu, seriji, pjevaču ili bendu, takav obožavatelj zna mnogo izravnih citata predmeta svog obožavanja i vrlo ih često koristi (Cavicchi, 1998.; Hills, 2002.; Duffett, 2013.), odnosno obožavatelji su najvidljiviji pojedinci unutar masovne publike (Lewis, 1992.; Perkins, 2012.). Dakle fenomen suvremenog obožavatelja unutar teorije o moći i otporu Joshue Meyrowitza predstavlja prijelaz iz pasivne publike, gdje je bio objekt manipulacije, prema aktivnom, kreativnom i otpornom pripadniku društva (Meyrowitz, 2008., prema Popović, 2011.). Autori Abercrombie i Longhurst smještaju pojam oboŽavatelja unutar spektra pojmova kao što su pripadnik kulta i entuzijast, pri čemu se ta tri pojma razlikuju samo prema specijalizaciji interesa, društvenoj organiziranosti i materijalnoj produktivnosti. Ostali autori poput Tullocha i Jenkinsa ignoriraju pojam kulta, te pojam obožavatelja uspoređuju s pojmom sljedbenika, pri čemu potonji ipak ne preuzima društveni identitet onog što slijedi (Abercrombie i Longhurst, 1998., prema Hills, 2002.; Tulloch i Jenkins, 1995., prema Hills, 2002.). Jenkins također procjenjuje obožavatelje prema intenzitetu emocionalne i intelektualne uključenosti (Jenkins, 1992., prema Cavicchi, 1998.), dok Brooker i Brooker ne smatraju nužnim da se svi pojedinci koji cijene neku osobu ili nečiji rad nužno definiraju kao obožavatelji, te ističu distinkciju između pojmova obožavatelja i predanog obožavatelja (engl. cult fan), koji je ipak više usmjeren prema grupi obožavatelja i njezinim aktivnostima od „običnog“ obožavatelja (Brooker i Brooker, 1996., prema Hills, 2002.). Obožavatelje je moguće definirati i u odnosu na tržište, pa su tako obožavatelji i njihovo ponašanje dio neprekidne, emocionalno karakterizirane potrošnje popularne kulture unutar kapitalističkog društva (Longhurst, 2007.; Grossberg, 2006.).

Nadalje, riječ obožavatelj u literaturi se vrlo rijetko pojavljuje u jednini, dakle pojmu obožavatelja od samog se početka daje kolektivni karakter. Ipak, Jenson razlikuje dva tipa obožavatelja, koji se javljaju kao kritički odgovor na suvremenu svakodnevnicu: opsjednutog pojedinca i histeričnu masu (Jenson, 1992.). Psihološka određenja obožavatelja tek se kratko osvrću na razvoj individualnog obožavanja kao ponašanja koje proizlazi iz neizbježnog kontakta s medijima. Prema psihologu Jibu Fowlesu pojedinci ,,puštaju zvijezde i slavne u najdublja područja uma kako bi utjecali na njihove emocije. Dopuštaju im pristup njima samima kao što ne dopuštaju nikom drugom oko sebe i upravo zbog te povezanosti divljenje često prelazi u imitaciju životnog stila" (Fowles, 1992., prema Cavicchi, 1998.:41). Dakle obožavatelji se uvijek

1 Riječ je prvi puta uprotrebljena 1903. godine, a nastala je spajanjem engleske riječi fan (obožavatelj) i sufiksa - dom. Osim u kontekstu grupe obožavatelja koristi se i kao skupna imenica za sve aktivnosti i tipična ponašanja obožavatelja (Oxford Dictionary, 2006.). 
definiraju u odnosu na zvijezde, tj. nekoga ili nešto poznato, oni su zapravo društveni odgovor na postojanje zvijezda. U medijima prožetom svijetu utjecaji poznatih osoba i medijski sadržaji postaju uzori velikom broju pojedinaca koji se s njima uključuju u ,,umjetne društvene odnose“ (Caughey, 1978., prema Jenson, 1992.:11). Takvi odnosi mogu, nažalost, poprimiti i zastrašujuće razmjere te rezultirati tragedijom, primjerice kada obožavatelj ubije slavnu osobu s kojom je razvio upravo takvu vrstu odnosa. Obožavatelj kao opsjednuti pojedinac uglavnom odgovara profilu usamljene osobe koja je konstruirala odnos s osobom ili predmetom svog obožavanja te na temelju tog odnosa djeluje.

Nasuprot usamljenom pojedincu, u kulturi obožavatelja javljaju se histerične mase, uglavnom adolescenata, koje dominiraju unutar sporta ili glazbene industrije. Fiske ih smatra sklonima kulturi niske kvalitete (Fiske, 2002.). Medijska prezentacija, ali i sami tekstovi, primjerice, rock ili metal glazbe stvaraju počevši od 1950-ih godina temelje nastajanju histerične, glasne, vrišteće mase koja se poistovjećuje s glazbom koju sluša (Jenson, 1992.). Fandom, odnosno grupu obožavatelja i njihove karakteristike, možemo promatrati u kontekstu glazbenog interkulturalizma, koji je u svom izvornom značenju koncept koji polazi od pluraliteta kultura i njihove jednakopravnosti, ali i aktivnog suodnosa, pri čemu upravo dimenzija dijaloga među kulturama daje interkulturalizmu otvorenost i društvenu dimenziju dodira (Previšić, 1994.). Stoga je uputno poimati suvremenu glazbu kao jedan od elemenata unutar konstrukcije društvenog kapitala, kao način na koji pojedinac seže van individualnog identiteta i oblikuje novi, zajednički, stvarajući pritom osjećaj pripadnosti određenoj zajednici, oblikujući zajednički identitet (Wright, 2012.). Taj kolektivni karakter prisutan je i u oblikovanju internetskih zajednica te interakcije unutar njih, pri čemu već postojeći obožavatelji rado dočekuju nove, uključuju ih u svoje aktivnosti i svakodnevnicu (Duffett, 2013.). Nadalje, Finnegan ističe važnost predanosti ljudi glazbi ili glazbeniku prilikom konstrukcije individualnog i grupnog identiteta, dočim se Crafts i suradnici usmjeravaju na aspekt emocionalne uključenosti pojedinaca u glazbeni žanr ili glazbenika kojeg slušaju i slijede, koji doprinosi izgradnji osjećaja sebstva i odnosa s drugima (Finnegan, 1989.; Crafts i sur., 1993., prema Cavicchi, 1998.).

Kako bismo objasnili koncept životnih ciljeva korišten u ovom istraživanju, potrebno ga je razdvojiti od pojma ciljeva, koji se najčešće definiraju kao unutarnji prikaz željenih ishoda, događaja ili procesa koji vode ponašanje, misli i djelovanje pojedinca te životu daju smisao i strukturu (Austin i Vancouver, 1996.; Emmons, 1986., prema Tucak Junaković, 2015.). Za razliku od nekih jednostavnih, svakodnevnih ciljeva, koncept životnih ciljeva označava ključnu orijentacijsku točku u životima pojedinaca (Pöhlmann i Brunstein, 1997., prema Tucak Junaković, 2015.). Prema njima se ponašanje pojedinca usmjerava i sukladno njima on razvija vlastiti identitet (Emmons, 1986.). U ovom je istraživanju korištena skraćena verzija skale životnih ciljeva autora Pöhlmanna i Brunsteina, koji životne ciljeve konceptualiziraju kroz dvije općeljudske tendencije, djelovanje (engl. agency) i zajedništvo (engl. community) (Pöhlmann i Brunstein, 1997.). Dakle u slučaju ovog istraživanja životni ciljevi povezani s ljudskom tendencijom djelovanja bili bi ciljevi moći i ciljevi postignuća, dok na zajedništvo upućuju ciljevi altruizma i intimnosti. S obzirom na to da su životni ciljevi izrazito povezani s osjećajem dobrobiti (Tucak Junaković, 2015.), njihovo 
dovođenje u vezu s osobnim značajkama pripadnika grupe obožavatelja Cellogirls u ovom istraživanju ima za svrhu potpunu, objektivnu i subjektivnu karakterizaciju te društvene grupe, kako na psihološkoj razini pojedinca tako i na društvenoj razini u kontekstu multikulturalizma.

Internet je danas prva asocijacija vezana za grupe obožavatelja i fandom općenito. Osim što pruža pristup velikom broju informacija u vrlo kratkom vremenu, omogućuje i dijeljenje ideja među istomišljenicima. Upravo su glazbeni obožavatelji oni koji su još od samih početaka digitalnih medija i interneta brisali granice kultura i država i širili glazbu na globalnoj razini (Baym, 2007.; Perkins, 2012.). Prve virtualne zajednice obožavatelja koje nisu povezane s televizijskim sadržajima pojavljuju se još kasnih 1970-ih i ranih 1980-ih u obliku grupnih pisama i Usenet foruma, a kreiraju ih obožavatelji glazbene grupe R.E.M. S povećanjem broja članova zajednica seli s grupnih mailing lista na forumske rasprave, a samim tim povećava se njezina dostupnost široj javnosti te potreba stalnih članova za traženjem veće doze privatnosti. Glazbeni obožavatelji ujedno su i jedan od glavnih razloga stvaranja prvih društvenih mreža 2000. godine. Osim što omogućavaju komunikaciju glazbenik - obožavatelj, društvene mreže postaju medij međusobnog povezivanja obožavatelja sličnih ili istih glazbenih interesa, a računi i internetski algoritmi omogućuju oblikovanje zajednica temeljenih na preferiranom glazbenom žanru, pristup brojnim informacijama o pojedincima $s$ kojima se dijeli glazbeni interes te u konačnici ostvarivanje prisnih, prijateljskih i gotovo obiteljskih odnosa na temelju istovjetne ljubavi prema glazbi (Baym, 2007.). Prisutnost i razvoj tehnologije obožavateljske prakse ubrzava, a njihove interakcije umnožava, zahvaljujući mogućem prijenosu gotovo ili u potpunosti uživo svih aktivnosti vezanih za predmet obožavanja, upoznavanja, odlaske na koncerte i slično (Bennett, 2012.). Stoga online grupe obožavatelja u pravom su smislu društvene grupe pojedinaca s ustaljenom strukturom, organizacijom, normama i aktivnostima, koje postaju zanimljiv izvor informacija i oblikuju brojna suvremena istraživačka pitanja. Te su zajednice konstruirane prema principu ,umreženog individualizma“, koji povezuje pojedince željne pripadanja nekoj grupi, iskazane zainteresiranosti za ostale njezine pripadnike, poistovjećivanja s njima i sudjelovanja u aktivnostima, odnosno riječ je o zajednicama visoke afektivne važnosti za pojedinca koje prerastaju geografska određenja pripadanja nekoj društvenoj grupi (Wellman, 2001., prema Baym, 2007.).

Svijet fandoma uključuje nekoliko temeljnih aktivnosti i specifičnih pojmova. Pripadanje nekom fandomu vidljivo je unutar identifikacije pojedinaca s konstruiranim imenima grupa obožavatelja. Primjerice obožavatelji franšize Harry Potter nazvali su se Potterheads, obožavatelji Zvjezdanih staza Trekkies, u glazbenom svijetu ističu se obožavatelji Lady Gage - Little monsters, Justina Biebera - Beliebers, Taylor Swift - Swifties te britanskog benda One Direction - Directioners i brojni drugi. Svaka grupa, uz ime uglavnom stvoreno izvedenicom od imena osobe ili sadržaja koji se prati, posjeduje i specifičan simbol. Shvaćanje fandoma kao društvene prakse najbolje se očituje kroz produkciju raznih tekstova, pjesama i ostalih artefakata koji djeluju kao medij oko kojeg se zajednica obožavatelja okuplja i o kojem diskutira. Navedeni predmeti ili tekstovi predstavljaju za obožavatelje objekt identitetskog poistovjećivanja sa zajednicom i razvijaju osjećaj pripadnosti određenom fandomu (Popović, 2011.). 
Hrvatski violončelistički duo 2CELLOS, koji popularnost duguje suvremenim društvenim promjenama i tehnološkim naprecima unutar glazbenoga svijeta, svojom je glazbom prevladao granice različitih svjetskih kultura te utjecao na stvaranje svjetske zajednice obožavatelja, koja prema svojim sociokulturnim obilježjima oblikuje nove oblike supkultura. Te različite, virtualne, online, Facebook i Twitter grupe obožavatelja, koji su sami sebe nazvali Cellogirls, primjer su društvene grupe s postavljenom društvenom strukturom, prividnom hijerarhijom, ulogama, normama i vrijednostima, svojevrsno društvo u malom koje povezuje upravo naklonjenost tom hrvatskom duu. Takvu grupu obožavatelja, kao dio potkulturnog kapitala, karakterizira visoka interaktivnost i obostrani utjecaj, kako glazbe na njezino djelovanje tako i obožavatelja na glazbenu industriju. Obožavatelji djeluju u ulozi najistaknutijih potrošača glazbe kao robe, izgrađujući unutar toga odnosa vlastite identitete i značenja svakodnevnice.

Cilj provedenog istraživanja bio je istražiti osnovne značajke obožavatelja dua 2CELLOS, i to njihove socijalne značajke (radni i obrazovni status, visinu primanja, bračni status, broj djece i sl.) te životne ciljeve, kao i utvrditi odnos životnih ciljeva i društvenih značajki obožavatelja. S obzirom na to da grupe obožavatelja tvore specifičnu društvenu, u slučaju ovog istraživanja, globalnu grupu, odnos njihovih životnih ciljeva te njihovih društvenih značajki smješten je u kontekst kulture, globalizacije i multikulturalizma. Dakle očekuje se kako će pojedinci - obožavatelji, okupljeni oko ovog specifičnog, ne-žanrovskog tipa glazbe, pripadajući različitim kulturama te društvenim miljeima ipak dijeliti specifične Životne ciljeve, koji su ih doveli u međusobni odnos i izgradili potrebu za pripadanjem grupi obožavatelja. U istraživanje se krenulo od pretpostavke kako su obožavatelji uglavnom mlađe životne dobi, ženskog spola, izvan bračnih/partnerskih zajednica te bez djece. Kada je riječ o glazbenom obrazovanju i preferencijama, pretpostavili smo da obožavatelji nemaju glazbeno obrazovanje, a kao preferirane glazbene žanrove očekivali smo mainstream-popularne izričaje i umjetničku glazbu. Kada je riječ o domenama životnih ciljeva, pretpostavili smo da će s obzirom na očekivanu dobnu strukturu uzorka ciljevi intimnosti biti dominantni, kao i da će ciljevi postignuća i moći biti manje izraženi. S obzirom na odnos životnih ciljeva i sociodemografskih značajki obožavatelja pretpostavljena je viša izraženost ciljeva intimnosti kod mlađih sudionika, kao i viša izraženost ciljeva moći i postignuća kod sudionika s višim primanjima te višim razinama obrazovanja. Naime, prema poznatim razvojnim teorijama, primjerice Eriksonovoj teoriji psihosocijalnog razvoja (Erikson, 1980.) ili teoriji razvojnih zadataka (Havighurst, 1972.), razdoblje mlađe odrasle dobi obilježeno je intimnošću bilo kao psihosocijalnom razvojnom krizom ili kao jednim od nekoliko razvojnih zadataka. Nadalje, istraživanja koja su se bavila rodnim razlikama u izraženosti pojedinih motiva ili vrijednosti kod pojedinaca uputila su na jasne rodne razlike, pri čemu su kod muškaraca izraženiji motivi postignuća i moći, a kod žena povezanosti i intimnosti (Denzinger i sur., 2016.), odnosno žene u odnosu na muškarce manje vrednuju moć i postignuće (Schwartz i Rubel, 2005.).

Navedene su pretpostavke proizašle iz pregleda literaturnih izvora na temu grupa obožavatelja, ali i iz konkretnog naziva koji si je ova grupa obožavatelja sama odabrala. Naime konkretno ime Cellogirls implicira kako je riječ uglavnom o ženskim osobama, mlađe životne dobi, izvan bračnih/partnerskih zajednica te bez djece. Nadalje, pretpostavka o preferiranim glazbenim žanrovima utemeljena je na tipu glazbe koji duo 2CELLOS najčešće i izvodi i sukladno kojem se i promovira, a to je upravo spoj rock i 
popularne glazbe s klasičnim notama. U medijskim istupima članovi dua uvijek ističu kako je jedan od njihovih ciljeva glazbom prevladati razlike među žanrovima i objediniti obožavatelje više različitih glazbenih izričaja.

\section{Metoda istraživanja}

\subsection{Uzorak i postupak istraživanja}

U istraživanju je sudjelovalo ukupno 188 sudionika iz 37 različitih zemalja svijeta (Novi Zeland, Australija, Tajland, Malezija, Libanon, Japan, Izrael, Armenija, Meksiko, Čile, Brazil, Argentina, SAD, Kanada, Ujedinjeno Kraljevstvo, Turska, Švedska, Španjolska, Srbija, Slovenija, Rusija, Rumunjska, Portugal, Poljska, Njemačka, Norveška, Malta, Makedonija, Mađarska, Italija, Francuska, Estonija, Češka, Bugarska, Belgija, Austrija i Hrvatska). S obzirom na raspršenost globalnog uzorka, korištena je online inačica anketnog upitnika konstruiranog za potrebe ovog istraživanja. Sudionici su uzorkovani svojevrsnom online inačicom snowball metode uzorkovanja, pri čemu je poveznica za online anketu dijeljena unutar zatvorenih Facebook grupa obožavatelja. Cilj je bio prikupiti osnovne sociodemografske podatke, podatke o glazbenim navikama te kategorizirati životne ciljeve grupe obožavatelja dua 2CELLOS. U uzorku je bilo 92,02\% žena i 7,98\% muškaraca, što je s obzirom na vrstu obožavatelja bilo i očekivano. Uzorak sudionika podijeljen je prema razvojnim značajkama dobnih skupina na tri dijela, kasne adolescente (do 21 godinu starosti), mlađu odraslu dob (do 45 godina) te odraslu i stariju dob (više od 46 godina), pri čemu je udio sudionika do 21 godinu starosti iznosio 23,94\%, od 22 do 45 godina $53,72 \%$, a starijih od 46 godina bilo je 22,34\%.

Istraživanje je provedeno u razdoblju od rujna 2015. do kraja travnja 2016. godine, tijekom kojeg je anketa bila dostupna na internetskoj stranici SurveyMonkey.com. Prikupljeni podaci analizirani su primjenom statističke aplikacije STATISTICA12.

\subsection{Instrument istraživanja}

Anketni upitnik, izrađen na engleskom jeziku zbog strukture uzorka, sastojao se od dvaju dijelova. Prvi je dio uključivao 18 pitanja zatvorenog tipa kojima su prikupljeni podaci o relevantnim sociodemografskim značajkama sudionika (spol, dob, zemlja, bračni status, broj djece, razina obrazovanja, radni status, visina i izvor prihoda, religijska pripadnost, glazbeno obrazovanje). Sva su pitanja u prvom dijelu upitnika bila zatvorena, s unaprijed ponuđenim odgovorima, pri čemu je zadatak sudionika bio odabrati jednu od ponuđenih mogućnosti. Drugi dio upitnika bila je Skraćena verzija upitnika važnosti životnih ciljeva (Tucak Junaković, 2008.), koja predstavlja adaptaciju Upitnika životnih ciljeva autora Pöhlmanna i Brunsteina (1997.). Upitnik se sastoji od 16 životnih ciljeva, koji se odnose na četiri domene životnih ciljeva: ciljeve intimnosti, altruizma, moći i dostignuća. Zadatak je sudionika bio procijeniti koliko im je važno postići svaki od 16 ciljeva na skali Likertova tipa od pet stupnjeva, gdje 1 znači „uopće mi nije važno“, a 5 znači „vrlo mi je važno“. Provedena eksploratorna 
faktorska analiza metodom glavnih komponenata uz varimax normaliziranu rotaciju potvrdila je četverofaktorsku strukturu te su formirani ukupni rezultati za četiri podskale, odnosno četiri domene životnih ciljeva. Koeficijenti pouzdanosti iznosili su Cronbach $\alpha=, 78$ za podskalu altruizma, Cronbach $\alpha=, 80$ za ciljeve moći, Cronbach $\alpha=, 81$ za ciljeve intimnosti te Cronbach $\alpha=, 84$ za ciljeve dostignuća.

\section{Rezultati}

U tablici 1. prikazani su podaci prikupljeni dijelom upitnika koji se odnosi na sociodemografske značajke sudionika.

Tablica 1.

Sociodemografske značajke sudionika istraživanja

\begin{tabular}{|c|c|c|}
\hline Varijabla & kategorije & $\%$ sudionika \\
\hline \multirow[t]{4}{*}{ seksualna orijentacija } & heteroseksualna & 91,53 \\
\hline & homoseksualna & 2,12 \\
\hline & biseksualna & 4,76 \\
\hline & ostalo & 1,59 \\
\hline \multirow[t]{7}{*}{ bračni status } & samci & 49,47 \\
\hline & u romantičnoj vezi & 9,57 \\
\hline & u (izvan)bračnoj zajednici & 26,60 \\
\hline & u kohabitaciji & 5,32 \\
\hline & razvedeni & 6,91 \\
\hline & udovci/udovice & 1,59 \\
\hline & Ostalo & 0,54 \\
\hline \multirow[t]{3}{*}{ broj djece } & nijedno & 60,32 \\
\hline & jedno & 38,10 \\
\hline & ostalo & 1,58 \\
\hline \multirow[t]{5}{*}{ Obrazovanje } & Osnovno & 2,54 \\
\hline & \begin{tabular}{|l|} 
srednjoškolsko \\
\end{tabular} & 30,16 \\
\hline & visoko (prvostupnici ili magistri) & 59,26 \\
\hline & doktorat & 4,23 \\
\hline & ostalo & 3,70 \\
\hline \multirow[t]{7}{*}{ radni status } & još se školuje & 34,92 \\
\hline & stalno zaposleni & 31,22 \\
\hline & povremeno zaposleni & 8,47 \\
\hline & samostalna djelatnost (samozaposleni) & 13,23 \\
\hline & nezaposleni/mirovina & 3,70 \\
\hline & u mirovini & 3,70 \\
\hline & Ostalo & 4,75 \\
\hline \multirow[t]{8}{*}{ visina primanja } & do 100 USD mjesečno & 22,75 \\
\hline & od 101do 500 USD mjesečno & 16,40 \\
\hline & od 501 do 1000 USD mjesečno & 14,29 \\
\hline & od 1001 do 2000 USD mjesečno & 15,87 \\
\hline & od 2001 do 3000 USD mjesečno & 8,47 \\
\hline & od 3001 do 5000 USD mjesečno & 11.64 \\
\hline & preko 5000 USD mjesečno & 6,88 \\
\hline & ostalo & 3,70 \\
\hline
\end{tabular}




\begin{tabular}{|c|c|c|}
\hline Varijabla & kategorije & $\%$ sudionika \\
\hline \multirow[t]{7}{*}{ glavni izvor prihoda } & roditelji i/ili skrbnici & 25,40 \\
\hline & stipendija & 6,88 \\
\hline & vlastiti rad (plaća) & 48,68 \\
\hline & primanja partnera & 10,58 \\
\hline & nasljedstvo & 1,06 \\
\hline & mirovina & 3,17 \\
\hline & ostalo & 4,23 \\
\hline \multirow[t]{5}{*}{ religijska pripadnost } & kršćani & 57,67 \\
\hline & ateisti ili ne pripadaju nijednoj vjeri & 30,68 \\
\hline & islam & 4,23 \\
\hline & budizam & 3,17 \\
\hline & ostali & 4,25 \\
\hline \multirow[t]{5}{*}{ politička orijentacija } & liberalna & 19,58 \\
\hline & konzervativna & 9,52 \\
\hline & centar & 11,64 \\
\hline & nikakvo opredjeljenje & 55,56 \\
\hline & ostalo & 3,70 \\
\hline \multirow[t]{6}{*}{ glazbeno obrazovanje } & nema nikakvo & 36,51 \\
\hline & samouki & 12,70 \\
\hline & privatna poduka & 26,98 \\
\hline & osnovna ili srednja glazbena škola & 12,70 \\
\hline & akademska glazbena naobrazba & 2,65 \\
\hline & Ostalo & 7,94 \\
\hline
\end{tabular}

Glazbeni ukus sudionika procijenjen je na temelju njihovih odabira glazbenih žanrova, pri čemu je ponuđeno ukupno 16 glazbenih žanrova, sukladno popisu glazbenih žanrova s internetske stranice MusicGenres, te je sudionicima ostavljena mogućnost otvorenog odgovora ukoliko preferirani žanr nije ponuđen. Preferencije glazbenih žanrova koji su bili najčešće odabrani prikazane su na slici 1 . Vidljivo je da se većina sudionika opredijelila za rock, klasičnu i popularnu glazbu, dok su ostali žanrovi odabirani sa značajno manjom učestalošću. Ovdje je bitno istaknuti kako je glazba koja je oblikovala grupu obožavatelja proučavanu u ovom istraživanju specifična upravo zbog žanrovske nepripadnosti. Ipak, riječ je o fenomenu koji objedinjuje često teorijski suprotstavljene klasičnu i popularnu glazbu, te stvara novu, svjetsku glazbu bez žanrovske podjele.

Kada je riječ o posjećivanju glazbenih koncerata, manje od deset koncerata u životu posjetilo je 27,51\% sudionika, 11 - 20 koncerata 26,46\% sudionika, 21 - 50 koncerata $25,4 \%$ sudionika, a ostali $(20,63 \%)$ su posjetili preko 50 koncerata. Učestalost posjećivanja koncerata dua 2CELLOS manja je nego što bi se očekivalo: 48,15\% sudionika nije bilo ni na jednom njihovom koncertu, $41,27 \%$ sudionika posjetilo je 1 - 2 koncerta, 7,94\% 3 - 5 koncerata, a 2,12\% sudionika posjetilo je 6 - 15 njihovih koncerata. 
Slika 1.

Glazbene preferencije sudionika

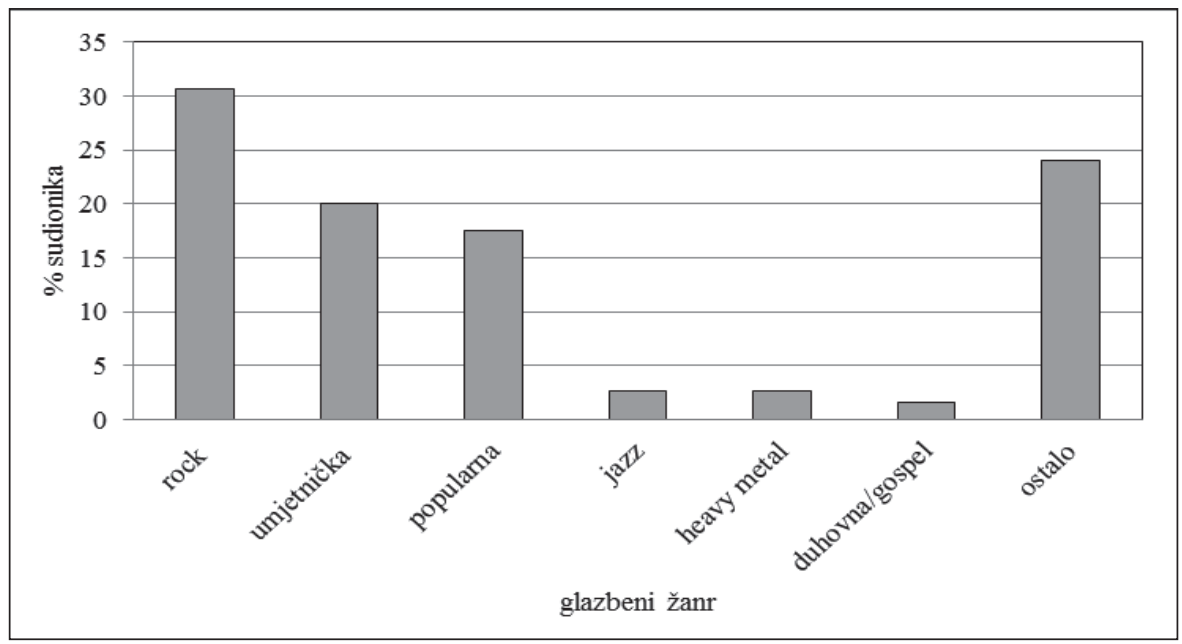

Na slici 2. prikazani su odgovori sudionika na pitanje o posjedovanju profila i korištenju različitih društvenih mreža. Pri tome se od sudionika tražilo da označe sve društvene mreže kojima se koriste (uslijed čega je ukupni postotak odgovora veći od 100). Može se zaključiti da je Facebook i dalje najpopularnija društvena mreža, odabralo je nešto manje od 90\% sudionika, slijede Twitter, koji koristi nešto više od $60 \%$ sudionika, te Instagram, koji je odabralo nešto manje od 50\% sudionika. Kada se zbroje svi odgovori i podijele s brojem sudionika, rezultati pokazuju da svaki sudionik ima profil na prosječno oko tri društvene mreže.

Slika 2.

Udio sudionika koji imaju profil i aktivno koriste društvene mreže

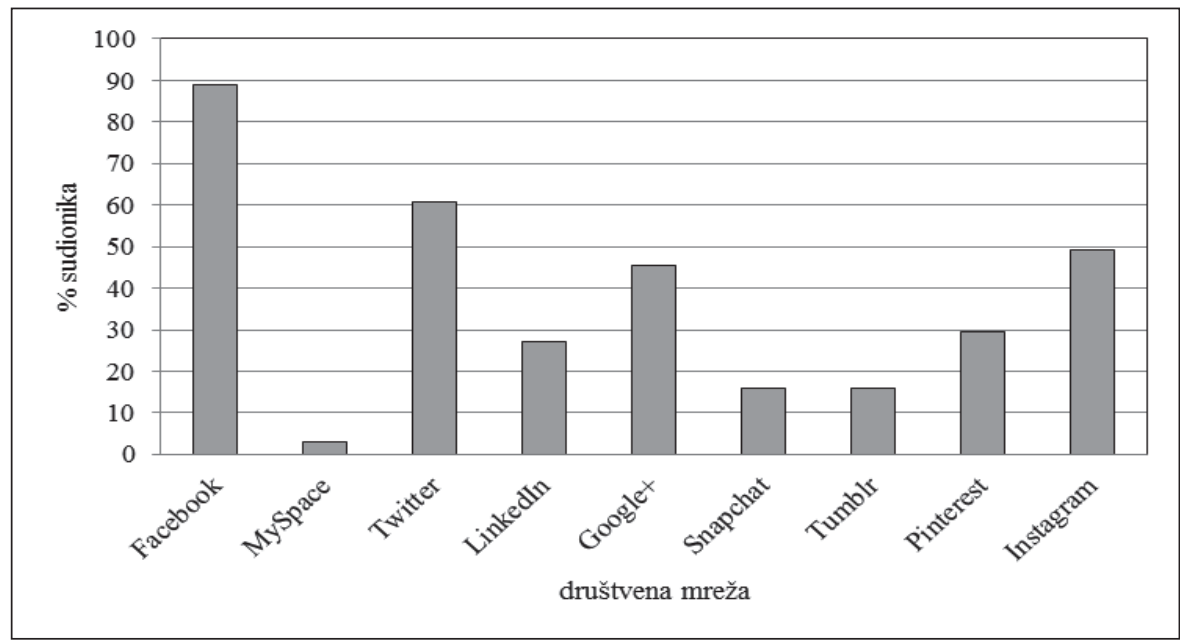


Na slici 3. prikazani su odgovori sudionika na Upitniku životnih ciljeva, odnosno ukupni prosječni rezultati sudionika za četiri domene ciljeva. Vidljivo je da su sudionici postigli najviši rezultat na domeni intimnosti i domeni postignuća, nešto niži rezultat ostvaren je za domenu altruizma, a sudionici su najmanje važnim procijenili ostvarivanje ciljeva moći.

Slika 3.

Izraženost domena životnih ciljeva obožavatelja

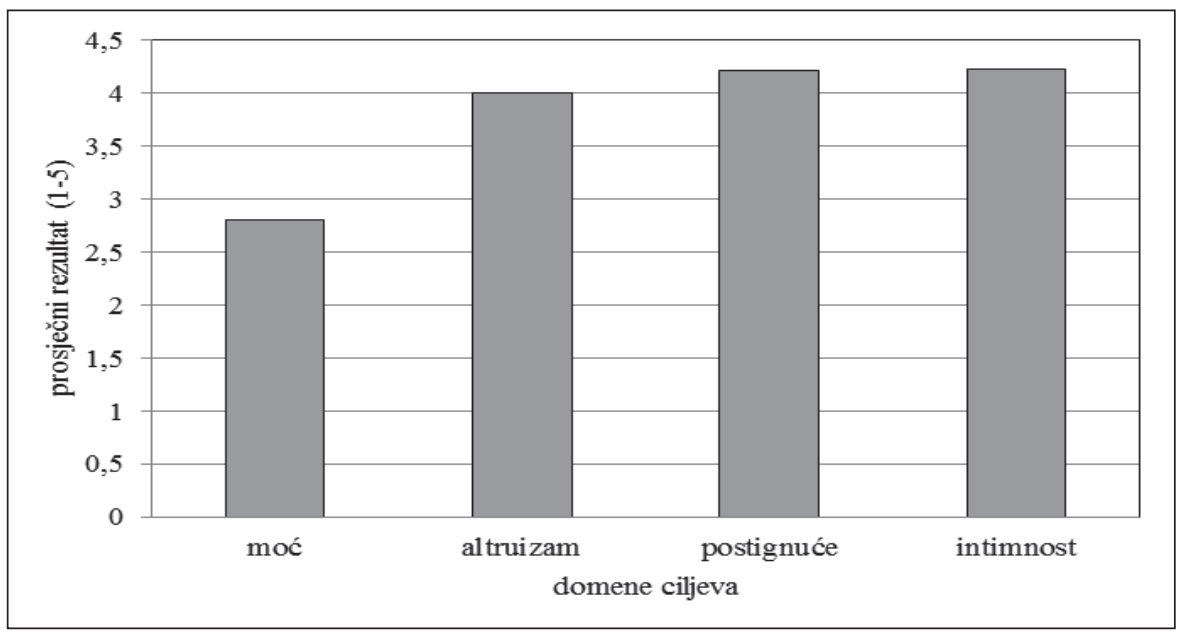

Kako bi se ispitale razlike u domenama životnih ciljeva s obzirom na neke sociodemografske značajke (bračni status, radni status), provedeno je nekoliko jednosmjernih analiza varijance. Pri tome su pojedine kategorije nezavisnih varijabli spojene budući da je u nekim kategorijama bio suviše mali broj sudionika, te ne bi bilo opravdano raditi takve usporedbe. Stoga su, kada je riječ o bračnom statusu, uspoređeni životni ciljevi među onima u bračnoj/izvanbračnoj zajednici, samcima te razvedenima/udovcima. Kada je riječ o radnom statusu, uspoređeni su rezultati sudionika koji se još školuju (studenata), zaposlenih i nezaposlenih.

Jednosmjerne analize varijance provedene na rezultatima domena životnih ciljeva s bračnim statusom kao nezavisnom varijablom pokazale su da postoje značajne razlike u domenama intimnosti $(\mathrm{F}=3,87$; $\mathrm{df}=2,185 ; \mathrm{p}=, 022)$ i moći $(\mathrm{F}=3,71$; df $=2,185 ; \mathrm{p}=, 026)$, dok u ostalim dvjema domenama nije utvrđen značajan efekt bračnog statusa $\left(\mathrm{F}_{\text {postignucé }}=0,46 ; \mathrm{df}=2,185 ; \mathrm{p}=, 633 ; \mathrm{F}_{\text {altruizam }}=1,011 ; \mathrm{df}=2,185 ; \mathrm{p}=\right.$ ,366). Naknadna je analiza razlika po skupinama za domenu intimnosti pokazala da se značajno razlikuju sudionici u bračnoj/izvanbračnoj zajednici od onih razvedenih (Scheffe test, $\mathrm{p}<, 05$ ) te samci u odnosu na razvedene/udovce (Scheffe test, $\mathrm{p}<$ ,05). Pri tome je najviši rezultat na intimnosti u skupini sudionika koji su u bračnoj/ izvanbračnoj zajednici $(M=4,42)$, potom u skupini samaca $(M=4,16)$ te u skupini razvedenih/udovaca $(M=3,96)$. Za domenu moći naknadna je analiza pokazala da se značajno razlikuju samo samci i razvedeni (Scheffe test, $\mathrm{p}<, 05$ ). Najviši je rezultat utvrđen u skupini samaca $(M=2,94)$, potom u skupini sudionika koji su u bračnoj/ 
izvanbračnoj zajednici $(\mathrm{M}=2,78)$, a najniži rezultat u skupini razvedenih/udovaca $(\mathrm{M}=2,32)$.

Nadalje, jednosmjerne analize varijance provedene na rezultatima domena životnih ciljeva s radnim statusom kao nezavisnom varijablom pokazale su da postoje značajne razlike u domenama moći $(\mathrm{F}=10,91 ; \mathrm{df}=2,185 ; \mathrm{p}=, 000)$ i postignuća $(\mathrm{F}=$ $3,23$; df $=2,185 ; \mathrm{p}=, 042)$, dok u ostalim dvjema domenama nije utvrđen značajan efekt radnog statusa $\left(\mathrm{F}_{\text {intimnost }}=0,02 ; \mathrm{df}=2,185 ; \mathrm{p}=, 981 ; \mathrm{F}_{\text {altruizam }}=1,834 ; \mathrm{df}=2,185\right.$; $\mathrm{p}=, 162$ ). Naknadna je analiza po skupinama za domenu moći pokazala da se sve skupine međusobno značajno razlikuju (Scheffe test, $\mathrm{p}<, 05$ ), pri čemu je najviši rezultat utvrđen u skupini sudionika koji se još školuju, odnosno studenata $(\mathrm{M}=$ $3,17)$, zatim u skupini zaposlenih $(M=2,69)$ te u skupini nezaposlenih/umirovljenih $(\mathrm{M}=2,27)$. Za domenu postignuća naknadna je analiza pokazala da postoji značajna razlika između studenata / onih koji se još školuju i nezaposlenih (Scheffe test, p < ,05) te između zaposlenih i nezaposlenih sudionika (Scheffe test, $\mathrm{p}<, 05$ ). Pri tome su viši rezultati utvrđeni u skupini studenata $(M=4,28)$ i zaposlenih $(M=4,27)$, a značajno niži u skupini nezaposlenih/umirovljenih $(\mathrm{M}=3,82)$.

Konačno, jednosmjerne analize varijance provedene na rezultatima domena životnih ciljeva s političkim opredjeljenjem kao nezavisnom varijablom pokazale su značajnu razliku jedino u domeni postignuća $(\mathrm{F}=3,04 ; \mathrm{df}=3,184 ; \mathrm{p}=, 03)$, dok u ostalima nije utvrđena značajna razlika s obzirom na političko opredjeljenje $\left(\mathrm{F}_{\text {intimnost }}=0,36\right.$; $\mathrm{df}=3,184 ; \mathrm{p}=, 777 ; \mathrm{F}_{\text {altruizam }}=2,347 ; \mathrm{df}=3,184 ; \mathrm{p}=, 069 ; \mathrm{F}_{\text {moć }}=0,76 ; \mathrm{df}=3,184 ; \mathrm{p}=$ ,518). U domeni postignuća najniži su rezultat postigli sudionici koji su naveli konzervativno političko opredjeljenje $(\mathrm{M}=3,78)$, dok između ostalih nije bilo značajne razlike $\left(\mathrm{M}_{\text {liberalni }}=4,34 ; \mathrm{M}_{\text {centar }}=4,40 ; \mathrm{M}_{\text {bez opredjeljenja }}=4,26\right)$.

Odnos između ostalih sociodemografskih varijabli i izraženosti domena životnih ciljeva izračunat je pomoću odgovarajućih koeficijenata korelacije, koji su prikazani u tablici 2.

Tablica 2.

Koeficijenti korelacija između osnovnih sociodemografskih varijabli i izraženosti životnih ciljeva obožavatelja

\begin{tabular}{|l|c|c|c|c|c|c|c|c|}
\hline & 1. & 2. & 3. & 4. & 5. & 6. & 7. & 8. \\
\hline 1. dob & 1,00 & & & & & & & \\
\hline 2. broj djece &, $51^{* * *}$ & 1,00 & & & & & & \\
\hline 3. razina obrazovanja &, 14 &, 11 & 1,00 & & & & & \\
\hline 4. prihodi &, $59^{* * *}$ &, $40^{* *}$ &, $21^{* *}$ & 1,00 & & & & \\
\hline 5. intimnost &,- 03 &, 04 &,- 01 &, 05 & 1,00 & & & \\
\hline 6. moć &,$- 26^{* *}$ &,- 14 &, 05 &,- 09 &, $36^{* *}$ & 1,00 & & \\
\hline 7. postignućc &,- 07 &,- 11 &, 08 &, $16^{*}$ &, $58^{* *}$ &, $45^{* *}$ & 1,00 & \\
\hline 8. altruizam &,- 08 &, 02 &, 00 &, 10 &, $61^{* *}$ &, $37^{* *}$ &, $58^{* *}$ & 1,00 \\
\hline
\end{tabular}

$* 0<, 05 ; * * 0,01$ 
Iz tablice 2. vidljivo je da postoji značajna povezanost između izraženosti svih životnih ciljeva, pri čemu je najviša povezanost utvrđena između altruizma i intimnosti (r $=, 61 ; \mathrm{p}<, 01$ ), što je i očekivano budući da se tu radi o ciljevima zajedništva (Tucak Junaković, 2008.). Kada je riječ o povezanosti osnovnih sociodemografskih varijabli i životnih ciljeva, pokazalo se da mlađi obožavatelji imaju izraženiji cilj moći ( $\mathrm{r}=$ -,26; p < ,01), kao i da je onima s višim prihodima važnije postignuće kao domena životnih ciljeva $(\mathrm{r}=, 16 ; \mathrm{p}<, 05)$. Ostale sociodemografske varijable nisu se pokazale povezanima s izraženošću životnih ciljeva obožavatelja.

\section{Rasprava}

Postoje stereotipi o obožavateljima određenih glazbenih izvođača ili žanrova. Primjerice obožavatelji rap glazbe obično se percipiraju kao opasni za druge, a obožavatelji heavy metal glazbe kao skloni autodestruktivnim ponašanjima (Fried, 2003.). Tako se i u ovo istraživanje krenulo od pretpostavke da su obožavatelji dua 2CELLOS uglavnom mlađe osobe ženskog spola izvan bračnih i/ili partnerskih zajednica, bez djece i bez glazbenog obrazovanja. Stoga je cilj provedenog istraživanja bio ispitati obilježja obožavatelja dua 2CELLOS, i to njihove socijalne značajke (radni i obrazovni status, visinu primanja, bračni status, broj djece i sl.) te izraženost životnih ciljeva. Rezultati su pokazali da su obožavatelji uglavnom mlađi sudionici, premda je udio starijih od 46 godina čak 22,34\%, što pokazuje da obožavatelji nisu isključivo dio mlađe populacije. Nadalje, obožavatelji su podjednako samci kao i oni u partnerskim zajednicama, a većina nema djecu ili ima najviše jedno dijete. Prema obrazovnom i radnom statusu većina obožavatelja ima neki oblik visokog obrazovanja te su uglavnom zaposleni ili se još uvijek školuju. Zanimljivo je da je većina sudionika bez političkog opredjeljenja, a s obzirom na religijsku orijentaciju nešto manje od trećine izjasnili su se kao ateisti, dok je najviše bilo pripadnika kršćanske zajednice.

Suprotno očekivanjima, većina obožavatelja ima neki oblik glazbenog obrazovanja, a samo jedna trećina sudionika navela je da nema nikakvo glazbeno obrazovanje. Kada je riječ o glazbenom ukusu, većina sudionika preferira rock glazbu i klasičnu glazbu, što je, kada se promotri opus instrumentalnog dua 2CELLOS, zapravo i logično. Naime članovi benda visoko su obrazovani klasični glazbenici, s diplomama prestižnih europskih glazbenih akademija. Svoju su pak globalnu popularnost stekli 2011. godine objavljivanjem videa s čelističkom obradom pjesme Michaela Jacksona Smooth Criminal na YouTubeu. Od tih početaka jedno od temeljnih obilježja njihovog glazbenog opusa spajanje je rock, pop i klasične glazbe, primjerice pjesme Iron Maidena The Trooper s djelom William Tell Overture Gioachina Rossinija ili pak Beethovenove Pete simfonije s pjesmom Whole Lotta Love britanskog benda Led Zeppelin. Stoga je moguće zaključiti da su glazbene preferencije sudionika u skladu s glazbenim žanrovima koje 2CELLOS na poseban način i izvodi. Ono što iznenađuje relativno je slaba posjećenost koncerata dua 2CELLOS, budući da gotovo polovina sudionika nije nikada bila na njihovom koncertu, većina ostalih na jednom ili dvama koncertima, a tek je 10\% sudionika bilo na više od dvaju koncerata. S obzirom na to da njihova globalna popularnost traje već više od pet godina te da održavaju koncerte na svim kontinentima, može se zaključiti kako posjećivanje koncerata nije jedna od važnijih 
aktivnosti i tipičnih ponašanja obožavatelja. Popularnost glazbenih izvođača danas je više nego ikad vezana uz digitalne medije, a ne živu glazbu. U doba ovisnosti o medijima celebrityji su uzori ili modeli svojim fanovima koji su s njima u umjetnim socijalnim relacijama (Caughey, 1978.). U tom kontekstu Jenson navodi i tzv. patološki fandom, koji ustvari predstavlja pokušaj psihološke kompenzacije. Riječ je o pokušaju nadomještanja unutarnjih nedostataka te traženju identiteta, povezanosti i smisla putem obožavanja poznatih osoba i grupne lojalnosti (Jenson, 1992.). Takvi obožavatelji, navodi autorica, imaju krhko samopoštovanje, slabe ili nepostojeće socijalne odnose te dosadan stvarni život. Odlasci na koncerte ili filmske festivale i televizijske konvencije gdje je moguć ,stvaran“ kontakt s idolima tek su usputne i rjeđe aktivnosti od već navedenih u virtualnom svijetu. No dijeljenje sadržaja, retweetanje objava drugih osoba o svom idolu, slanje izravnih poruka idolima, lajkanje stranica na Facebooku, praćenje osobnih profila zvijezda na Instagramu, pisanje blogova i sudjelovanje u diskusijama na Tumblru o najnovijim događajima u serijama, životima glumaca ili pjevača, kreiranje vlastitih fotografija ili kolaža s fotografijama iz omiljenih serija, filmova ili bendova, pisanje fanfiction priča, odabir i aktivno pripadanje grupi koja podržava određeni ljubavni par u filmu ili seriji (engl. shipping), korištenje popularnih hashtagova ${ }^{2}$ kako bi se povećala interaktivnost i postigao trending određene teme na Twitteru predstavlja aktivnosti koje danas postaju dio svakodnevice obožavatelja. Tome u prilog idu i podaci iz ovoga istraživanja, koji pokazuju da obožavatelji prosječno aktivno koriste barem tri društvene mreže, dok s druge strane rijetko posjećuju koncerte svojih glazbenih idola.

Među domenama životnih ciljeva sudionici su u prosjeku ciljeve zajedništva (intimnost i altruizam) procijenili važnima, prema vrlo važnima $\left(C_{\text {intimnost }}=4,5 ; C_{\text {altruizam }}=4,0\right.$; na skali od 1 do 5), dok su ciljeve djelovanja (moć i postignuće) u prosjeku procijenili osrednje važnima, iako je razlika između ciljeva moći i postignuća značajna $\left(\mathrm{C}_{\text {moć }}=2,75\right.$; $\mathrm{C}_{\text {posti- }}$ gnuće $=4,25$ na skali od 1 do 5). Obožavatelji se osrednje slažu u procjenama važnosti Životnih ciljeva (Kendallov koeficijent slaganja $=, 48$ ). Intimnost kao najistaknutiji među ciljevima u skladu je s poimanjem obožavatelja kao pojedinaca koji pokušavaju zadovoljiti svoju potrebu za intimnošću odnosima s predmetom ili predmetima obožavanja (Wang, 2016.) ili pak pojedincima s kojima se povezuju u svrhu zajedničkog obožavanja poznate osobe, zvijezde, grupe izvođača i drugih. To bi značilo da pojedinci koji se smatraju obožavateljima ne uspijevaju u stvarnome životu realizirati zadovoljavajuće socijalne odnose kroz koje ili u kojima bi uspješno zadovoljavali potrebu za intimnošću i povezanošću. Ostvarenje intimnosti očito im je vrlo važno, pa je moguće da sudjelujući u grupnom obožavanju dua 2CELLOS na određeni način ostvaruju i taj cilj. Zanimljivo je primijetiti kako je potreba za intimnošću izraženija u skupini sudionika koji su u bračnoj/izvanbračnoj zajednici nego kod samaca. Navedeno potvrđuje tezu Hortona i Wohla (1956.), prema kojoj obožavatelji osobno kreirajući karakteristike poznate osobe, zvijezde koju obožavaju, ostvaruju s njome parasocijalni odnos kako bi na-

2 Hashtag označava riječ ispred koje se piše znak \# (ljestve, engl. hash mark) koja služi za isticanje ključne riječi ili fraze na društvenim mrežama. Upotreba hashtagova omogućuje pretraživanje svih objava na društvenim mrežama koje su upotrijebile istu oznaku (Dictionary, 2016.). 
domjestili nedostatak potrebnih karakteristika kod bliskih osoba s kojima ostvaruju stvarne socijalne interakcije (Horton i Wohl, 1956., prema Wang, 2016.).

Potreba za pripadanjem grupi, koja se očituje kroz izraženu potrebu za ostvarivanjem intimnosti, u ovom je istraživanju popraćena izraženom potrebom mlađih sudionika za ostvarivanjem moći i postignuća. S obzirom na sve veću ulogu medija, a time i glazbe, u socijalizaciji pojedinaca, očite su sve češće identifikacije mladih s glazbom koju slušaju i s izvođačima koji je izvode. Obožavatelji koji se i dalje školuju, odnosno studenti, ističući potrebu za moći i postignućem očito se još uvijek ne identificiraju samo kao obožavatelji, odnosno ne prihvaćaju preuzimanje opće neprihvatljivog kulturnog identiteta izgrađenog na nečem tako trivijalnom kao što je film, serija, slavna osoba ili glazbena zvijezda (Hills, 2002.). Također, u mlađoj je dobi češće shvaćanje zvijezda, u ovom slučaju članova dua 2CELLOS, kao životnih uzora koji mladima svojom pričom o uspjehu postavljaju jasne ciljeve samoostvarenja, ambicioznosti, ostvarivanja snova i u konačnici ostvarivanja moći u svojoj poslovnoj domeni, odnosno glazbi. Navedeno potvrđuje rezultate etnografije Frasera i Browna, prema kojima obožavatelji ne samo da prate objekte svog obožavanja već i preuzimaju njihove životne norme i vrijednosti, što rezultira promjenama u osobnostima i identitetu obožavatelja (Fraser i Brown, 2002., prema Click i sur., 2013.). Ukoliko uzmemo u obzir kako među sudionicima istraživanja prevladavaju žene, ne iznenađuje činjenica kako one konzervativnog političkog opredjeljenja pokazuju najmanje izraženu želju za postignućem. Navedeno možemo opravdati tradicionalnim i patrijarhalnim shvaćanjem društva iz te političke perspektive, prema kojoj je muškarac dominantno taj koji ostvaruje postignuće u financijskom i poslovnom smislu, dok su žene više orijentirane na sfere intimnosti, odnosno osnivanje i vođenje obitelji.

\section{Zaključak}

Grupe obožavatelja u pravom su smislu društvene grupe pojedinaca s ustaljenom strukturom, organizacijom, normama i aktivnostima, koje postaju zanimljiv izvor informacija i oblikuju brojna suvremena istraživačka pitanja. Konstruirane su po principu ,,umreženog individualizma“ te povezuju pojedince željne grupne pripadnosti, kreirajući zajednice visoke afektivne važnosti bez obzira na prostorno-geografsko pripadanje identiteta pojedinca (Wellman, 2001., prema Baym, 2007.).

Rezultati ovoga istraživanja pokazali su kako su obožavatelji dua 2CELLOS relativno heterogena skupina, iako prevladavaju osobe ženskog spola, mlađe dobi, s nekim oblikom glazbenog obrazovanja, bez političkih preferencija, viših razina obrazovanja i osrednjih prihoda. Ciljevi intimnosti, postignuća i altruizma visoko su im i podjednako važni. Kada je riječ o tipičnim ponašanjima, treba istaknuti kako je posjećivanje koncerata zapravo slabo zastupljeno, a rezultati impliciraju kako su glavni vidovi obožavateljskih ponašanja preneseni dominantno na internet, odnosno društvene mreže. Prikazanom visokom potrebom za ostvarivanjem intimnosti ta grupa obožavatelja potvrđuje teorije o obožavateljima kao pojedincima koji sa slavnom osobom koju prate, pa makar samo i preko društvenih mreža i interneta, teže ostvariti prisan odnos i emocionalnu povezanost. Također, specifične poruke o uspjehu, 
marljivosti, trudu i zalaganju, koje u gotovo svim javnim nastupima i intervjuima ističu članovi dua 2CELLOS, zasigurno su uvjetovale visoku važnost postignuća i altruizma u životima članova grupe njihovih obožavatelja. S obzirom na to da je riječ uglavnom o pojedincima mlađe životne dobi, jasno je kako glazbenici kao što su njih dvojica, koji svoj globalni uspjeh i slavu duguju isključivo vlastitoj marljivosti i inovativnosti, postaju uzor pri izgradnji identiteta i uspjeha, odnosno nit vodilja u samoostvarenju svojih obožavatelja.

\section{Literatura}

1. Austin, J. T. and Vancouver, J. B. (1996). Goal constructs in psychology: Structure, process, and content. Psychological Bulletin, 120 (3): 338-375.

2. Baym, N. K. (2007). The new shape of online community: The example of Swedish independent music fandom. The First Monday, 12 (8). http://firstmonday.org/article/view/1978/1853. (Pregledano 30.5.2016.)

3. Bennett, L. (2012). Patterns of listening through social media: online fan engagement with the live music experience. Social Semiotics, 22 (5): 545-557.

4. Cavicchi, D. (1998). Tramps Like Us. Music E Meaning Among Springsteen Fans. New York, Oxford: Oxford University Press.

5. Click, M. A.; Lee, H. and Wilson Holladay, H. (2013). Making Monsters: Lady Gaga, Fan Identification, and Social Media. Popular Music and Society, 36 (3): 360379. www.tandfonline.com/doi/pdf/10.1080/03007766.2013.798546. (Pregledano 13.12.2016.)

6. Dictionary (2016). Hashtag. http://www.dictionary.com/browse/hashtag. (Pregledano 13.12.2016.)

7. Denzinger, F.; Backes, S.; Job, V.; Brandstätter, V. (2016). Age and gender differences in implicit motives. Journal of Research in Personality, 65: 52-61.

8. Duffett, M. (2013). Introduction: Directions in Music Fan Research: Undiscovered Territories and Hard Problems. Popular Music and Society, 36 (3): 299-304.

9. Emmons, R. A. (1986). Personal strivings: an approach to personality and subjective well-being. Journal of Personality and Social Psychology, 51: 1058-1068.

10. Erikson, E. H. (1980). Identity and the life cycle. New York: Norton.

11. Fiske, J. (2002). Popularna kultura. Beograd: Clio.

12. Fried, C. B. (2003). Stereotypes of Music Fans: Are Rap and Heavy Metal Fans a Danger to Themselves or Others? Journal of Media Psychology, 8 (3): 1-27.

13. Grossberg, L. (2006). Is There a Fan in the House? The affective sensibility of fandom, in: Marshall, P. D. (Ed.). The Celebrity Culture Reader. New York: Routledge, 196-222.

14. Havighurst, R. (1972). Developmental Tasks and Education. New York: David McKay.

15. Hills, M. (2002). Fan Cultures. London and New York: Routledge.

16. Jenson, J. (1992). Fandom as Pathology: The Consequences of Characterization, in: Lewis, L. A. (Ed.). Adoring Audiences: Fan Culture and Popular Media. London and New York: Routledge, 9-29.

17. Lewis, L. A. (1992). Introduction, in: Lewis, L. A. (Ed.). Adoring Audiences: Fan Culture and Popular Media. London and New York: Routledge, 1-6. 
18. Longhurst, B. (2007). Cultural Change and Ordinary Life. Berkshire, Milton Keynes: Open University Press.

19. MusicGenres (2016). Music Genres List. http://www.musicgenreslist.com/. (Pregledano 1.9.2017.)

20. Oxford Dictionary (2006). Fan. https://en.oxforddictionaries.com/definition/fan. (Pregledano 13.12.2016.)

21. Perkins, A. (2012). How devoted are you? An examination of online music fan behaviour. Annals of Leisure Research, 15 (4): 354-365.

22. Pöhlmann, K. and Brunstein, J. C. (1997). GOALS: Ein Fragebogen zur Messung von Lebenszielen. Diagnostica, 43: 63-79.

23. Popović, H. (2011). Media Text and Audiences: Discursive Constructions of Fandom. Medijske studije, 2 (3-4): 3-15.

24. Previšić, V. (1994). Multi- i interkulturalizam kao odgojni pluralizam, u: Matijević, M.; Pranjić, M. i Previšić V. (Ur.). Pluralizam u odgoju i školstuu. Zagreb: Katehetski salezijanski centar, 19-22.

25. Schwartz, S. H. and Rubel, T. (2005). Sex differences in value priorities: Crosscultural and multi-method studies. Journal of Personality and Social Psychology, 89: 1010-1028.

26. Tucak Junaković, I. (2008). Skraćena verzija upitnika važnosti životnih ciljeva, u: Penezić, Z.; Ćubela Adorić, V.; Proroković A.; Tucak Junaković, I. (Ur.). Zbirka psihologijskih skala i upitnika, 4. Zadar: Sveučilište u Zadru, 73-84.

27. Tucak Junaković, I. (2015). Doprinos životnih ciljeva nekim aspektima mentalne dobrobiti i zdravlju. Medica Jadertina, 45 (3-4): 87-95.

28. Wang, H. (2016). Social identity of Fans and its Interaction with Fandom. www. inter-disciplinary.net/critical-issues/wp-content/uploads/2014/05/Hao-TingWang-Celeb3-dpaper.pdf. (Pregledano 9.12.2016.)

29. Wright, R. (2012). Music Education and Social Transformation: Building Social Capital Through Music. Canadian Music Educator, 53 (3): 12-13. 
Izvorni znanstveni rad

Tea Gutović

University of Zagreb, Faculty of Humanities and Social Sciences, Croatia

e-mail: tgutovic@gmail.com

\title{
Ina Reić Ercegovac
}

University of Split, Faculty of Humanities and Social Sciences, Department of Psychology, Croatia

e-mail: inareic@ffst.hr

\section{Personal Characteristics and Life Goals of "Cellogirls" Fan Group}

\begin{abstract}
It is not easy to research and analyse the concept of fans and fan groups. In order to adequately comprehend and study their characteristics, principles, activities and behaviour patterns, both the social and cultural context are essential. This paper presents the results of research on some characteristics of 2CELLOS fans that was conducted on the sample of 188 respondents from all over the world. The data about relevant socio-demographic characteristics were collected by using an online questionnaire which consisted of close-ended questions; a shorter version of the scale for testing the importance of life goals was also applied. The survey results show that the 2CELLOS fan group is not homogeneous in its sociodemographic characteristics, although most members are young heterosexual women with a higher level of education, no clear political commitment and some kind of music education and experience. As for life goals, intimacy and achievement rank highest.
\end{abstract}

Key words: fans, 2CELLOS, Cellogirls, socio-demographic characteristics, music, life goals. 